\title{
STUDI PERILAKU DAN PRESTASI BELAJAR PENDIDIKAN AGAMA ISLAM PADA SISWA AUTIS DI SMP NEGERI 5 SURABAYA
}

\author{
Hayyan Ahmad Ulul Albab \\ Universitas Islam Lamongan (UNISLA), Lamongan \\ e-mail: hayyan.ahmad27@gmail.com
}

\begin{abstract}
Teacher quality is the teacher who has the ability to realize the goals of national education which has a pedagogical competence, personal competence, social competence and professional competence. Autism is a developmental disorder of behavior and talk so they were not able to hold social interaction and living in his own world. Inclusive education is a key method for dealing with children with autistic disorder. The basic principle of inclusive education is all children should have the opportunity to learn together with normal student. Qualitative research is research that aims to understand the phenomenon of what is experienced by the subjects of the study such behavior, perception, motivation and action in a holistic manner and to describe in words and language in a naturally specific context and by utilizing a variety of natural methods. Behavior of students with autism are basically all the same dipend on the difference in rates of autism symptoms. After that, the behavior of students with autism will be directed to behavior that reflects Islamic religion, such as acting polite against teachers, respect to teachers and adhere to what was ordered by the teacher. Second, the learning achievement of Islamic religious education that has been achieved quite encouraging students with autism. This achievement is evidenced by the completion of the subjects of Islamic religious education in accordance with the standards established school graduation and some non-academic achievements.
\end{abstract}

Keywords : Autism, Behavior, Achievement. 


\section{Pendahuluan}

Pendidikan mempunyai tanggung jawab yang sangat besar untuk mencerdaskan masyarakat bangsa ini. Tujuan pendidikan pada umumnya adalah menyediakan lingkungan yang memungkinkan para siswa untuk mengembangkan bakat dan kemampuannya secara optimal. Sehingga ia dapat mewujudkan dirinya dan berfungsi sepenuhnya sesuai dengan kebutuhan pribadinya dan kebutuhan masyarakat yang berada di lingkungannya. ${ }^{1}$

Dalam Keputusan Nasional yang tertera dalam UU No. 20 tahun 2003 disebutkan bahwa pendidikan nasional bertujuan untuk mengembangkan potensi peserta didik agar menjadi manusia yang beriman dan bertakwa kepada Tuhan Yang Maha Esa, berakhlak mulia, cakap, kreatif, mandiri dan menjadi warga negara yang demokratis serta bertanggung jawab. ${ }^{2}$

Upaya menjadikan pendidikan yang berkualitas, salah satunya adalah tersedianya guru yang berkualitas. Guru yang berkualitas adalah guru yang memiliki kemampuan untuk mewujudkan tujuan pendidikan nasional, yakni yang memiliki kompetensi pedagogik, kompetensi kepribadian, kompetensi sosial, dan kompetensi profesional. Tujuan pendidikan ini sangat penting diterapkan dalam pengajaran terutama jika kita sedang

\footnotetext{
${ }^{1}$ Utami Munandar, Kreatifitas dan Keberbakatan (Jakarta: Gramedia, 2002), 14.

${ }^{2}$ Undang-undang Republik Indonesia No. 20 tahun 2003 tentang Sistem Pendidikan Nasional (Bandung: Citra Umbara, 2003), 7.
} 
mendidik siswa yang berbeda dari siswa pada umumnya yaitu siswa dengan gangguan autis.

Autis merupakan suatu gangguan perkembangan yang menganggu fungsi kognitif, emosi dan psikomotorik. Oleh sebab itu, bisa dikatakan sebagai gangguan neurobiologis yang disertai dengan beberapa masalah seperti autoimunitas, gangguan pencernaan, dysbiosis pada usus, gangguan integrasi sensor dan ketidak seimbangan susunan asam amino. Beberapa penyebabnya diketahui antara lain keracunan logam berat ketika anak dalam kandungan, seperti timbal, merkuri, cadmium, spasma infanti, rubella kongental, seklerosis tuberosa, lipidosis serebral dan anomaly komosom $\mathrm{X}$ rapuh. Hal ini merupakan beberapa kondisi yang sering dijumpai. ${ }^{3}$

Masyarakat Indonesia pada dasarnya adalah masyarakat heterogen. Masyarakat yang dipenuhi dengan banyak budaya dan nilai-nilai moral supaya menjadi anak yang baik hati, berbakti kepada orang tua, berguna bagi dirinya, keluarga, masyarakat, agama, bangsa dan negaranya. Keluarga yang mempunyai anak dengan gangguan kesehatan baik fisik maupun psikis akan mengalami stress dan berusaha semaksimal mungkin untuk mengobatinya. Situasi yang dihadapi keluarga seperti ini akan terasa lebih sulit dan mencemaskan bila anak tersebut menderita autis.

Autis adalah suatu sindrom gangguan perkembangan anak yang sangat kompleks dan berat dengan penyebab yang sangat

\footnotetext{
${ }^{3}$ Trianto Safaria, Autisme (Yogyakarta: Graha ilmu, 2005), 3.
} 
bervariasi serta gejala klinik yang biasanya muncul pada tiga tahun pertama dari kehidupan anak tersebut. ${ }^{4}$

Autis merupakan suatu penyakit yang berkaitan dengan gangguan pertumbuhan otak, bermanifestasi pada gangguan perilaku termasuk gangguan konsentrasi, komunikasi dan interaksi sosial serta gangguan terhadap stabilisasi sampai kehilangan interes. Hal ini mengakibatkan banyak problem, seperti kesehatan, komunikasi dan cara beradaptasi karena dalam perjalanan hidupnya membutuhkan bantuan dari keluarga dan masyarakat di sekitarnya. Bentuk pelayanan masyarakat untuk anak autis adalah pendidikan yang disesuaikan dengan kondisi dan kebutuhan anak. Dalam mendidik anak autis memerlukan suatu pendekatan yang khusus sehingga mereka bisa mendapatkan pelayanan pendidikan yang sesuai dengan kebutuhannya. Hal ini sesuai dengan UU No. 23 tahun 2003 tentang perlindungan anak yang tertera dalam pasal 70 ayat 2 "setiap orang dilarang memperlakukan anak dengan mengabaikan pandangan mereka secara diskriminatif, termasuk labelisasi dan penyetaraan dalam pendidikan bagi anak-anak penyandang cacat.

Pendidikan inklusif adalah metode kunci untuk menangani anak-anak dengan gangguan autis. Prinsip dasar pendidikan inklusif adalah bahwa semua anak harus memperoleh kesempatan untuk bersama-sama belajar. Hal ini berarti bahwa

\footnotetext{
${ }^{4}$ Slamet Santosa, Psikologi Klinis (Jakarta: UI Press, 2003), 66.
} 
sekolah formal harus diperlengkap untuk melihat dan menanggapi kebutuhan-kebutuhan pelajar yang beranekaragam.

\section{Konsep Autis}

Pendapat Handojo, istilah autisme berasal dari kata auto yang berarti sendiri, yaitu anak yang menyandang autis dan seakan-akan hidup di dunianya sendiri ${ }^{5}$ atau suatu kelainan ketidakmampuan berinteraksi, komunikasi dan berbaur secara sosial. ${ }^{6}$ Anak autis adalah anak yang dalam proses pertumbuhan dan perkembangannya secara signifikan (bermakna) mengalami kelainan atau penyimpangan, kelainan itu bisa terjadi pada fisik, mental, intelektual, sosial, maupun emosional. Kemudian dapat kita pahami bahwa pengertian autis adalah nama dari sekelompok kelainan kebiasaan atau tingkah laku dengan ciriciri penyimpangan interaksi sosial, khususnya bahasa yang diucapkan, kontak mata, bahasa tubuh dan pendekatan sosial, terutama kekurangan hubungan sosial dengan orang lain.

Banyak pakar dalam bidang anak autis telah sepakat bahwa faktor-faktor yang menyebabkan anak autis adalah pada otak anak autisme dijumpai suatu kelainan. Faktor-faktor yang menyebabkan anak autis antara lain adalah:

\footnotetext{
5 Y. Handojo, Autisma Petunjuk Praktis dan Pedoman Materi untuk Mengajar Anak Normal Autis dan Perilaku Lain (Jakarta: Buana Ilmu Populer, 2003), 12.

${ }^{6}$ J. David Smith, Inklusi Sekolah Ramah untuk Semua (Bandung: Nuansa, 2006), 150 .
} 
a. Genetika (faktor keturunan) ditengarai adanya kelainan kromosom pada anak autisme, namun kelainan ini tidak berada pada kromosom yang selalu sama.

b. Infeksi virus dan jamur yang terdiri dari toksoplasmosis, rubella, candida yang menyebabkan tingkah laku yang tidak pantas dan masalah kesehatan pada anak autis.

c. Kekurangan nutrisi dan oksigenasi.

d. Polusi udara, air dan makanan.

e. Sensory interpretation errors yaitu rangsangan yang berasal dari reseptor visual, auditori, dan taktil yang mengalami proses yang kacau pada otak anak sehingga timbul persepsi yang semrawut, kacau atau berlebihan yang pada akhirnya menyebabkan kebingungan dan ketakutan pada anak. Akibatnya anak menarik diri dari lingkungan yang "menakutkan" tersebut."

Gejala-gejala autisme mulai tampak sejak masa yang paling awal dalam kehidupan mereka, gejala-gejala tersebut tampak ketika seorang manusia masih dalam tahap perkembangan bayi. Di sini bayi menolak sentuhan orangtuanya, tidak merespon kehadiran orangtuanya, melakukan kebiasaankebiasaan lainnya yang tidak dilakukan oleh bayi-bayi normal pada umumnya. Ketika memasuki umur di mana mereka seharusnya mulai mengucapkan beberapa kata, misalnya ayah, ibu tetapi pada kenyataannya bayi ini tidak berkata yang sedemikian rupa dan seterusnya. Di samping itu, ia juga

\footnotetext{
${ }^{7}$ Handojo, Autisma Petunjuk Praktis, 27.
} 
mengalami keterlambatan dalam beberapa perkembangan kemampuan lainnya. ${ }^{8}$

Dari sini dapat kita lihat ciri perilaku anak autis. Ciri-ciri khusus dan gejala-gejala yang timbul pada anak autis sangat komplek dan tergantung dari tingkat parah tidaknya anak autis yang sedang kita hadapi. Salah satu ciri dan gejala yang timbul pada umumnya yaitu tidak adanya kontak mata antara anak autis dan orang lain yang sedang menatapnya, bergerak berulangulang tidak seperti pada anak umumnya atau seusianya, suka dengan dunianya sendiri atau dunia hayalannya sendiri dan lainlain. Pada intinya anak autis mengalami masalah gangguan pada perkembangan perilaku dan berbicaranya sehingga mereka tidak mampu mengadakan interaksi sosial dan seolah-olah hidup dalam dunianya sendiri.

\section{Metode Penelitian}

Dalam penelitian ini, peneliti menggunakan metode penelitian kualitatif. Menurut Moleong, penelitian kualitatif adalah penelitian yang bermaksud untuk memahami fenomena tentang apa yang dialami oleh subjek penelitian misalnya perilaku, presepsi, motivasi dan tindakan secara holistik dan dengan cara deskripsi dalam bentuk kata dan bahasa pada suatu konteks khusus yang alamiah dan dengan memanfaatkan

${ }^{8}$ Derek Wood dkk, Kiat Mengatasi Gangguan Belajar (Yogyakarta: Kata Hati, 2005), 235. 
berbagai metode alamiah. ${ }^{9}$ Penelitian ini berorientasi pada gejala-gejala yang bersifat alamiah atau bersifat naturalistik dan mendasar dengan langsung terjun ke lapangan. ${ }^{10}$

Sedangkan jenis penelitian yang akan digunakan oleh peneliti adalah penelitian deskriptif. Menurut Mardalis, penelitian deskriptif bertujuan untuk mendeskripsikan apa-apa yang saat ini berlaku, di dalamnya terdapat upaya mendeskripsikan, mencatat, analisis dan menginterpretasikan kondisi-kondisi yang sekarang ini terjadi atau ada. ${ }^{11}$ Sebagai penelitian kualitatif yang bersifat deskriptif, maka penelitian ini tidak untuk menguji hipotesis atau tidak menggunakan hipotesa akan tetapi untuk memaparkan data dan mengolahnya secara deskriptif tentang fokus penelitian sesuai dengan data-data yang diperoleh. $^{12}$

Subjek penelitian merupakan sebuah sumber atau tempat di mana peneliti memperoleh keterangan yang ada hubungan dengan penelitian. Sedangkan menurut Suharsimi Arikunto, subjek adalah seorang atau lebih yang sengaja dipilih oleh peneliti guna dijadikan narasumber data yang dikumpulkan. ${ }^{13}$ Subjek penelitian dalam penelitian ini, antara lain: teman sekelas

9 Lexy J. Moleong, Metodologi Penelitian Kualitatif (Bandung: Remaja Rosda Karya, 2009), 6.

${ }^{10}$ Muhammad Nazir, Metode Penelitian (Bandung: Remaja Rosda Karya, 2010), 159.

11 Mardalis, Metode Penelitian Suatu Pendekatan (Jakarta: Bumi Aksara, 2011), 26.

${ }^{12}$ Mardailis, Metode Penelitian, 26.

13 Suharsimi Arikunto, Manajemen Penelitian (Yogyakarta: Rineka Cipta, 2012), 113. 
siswa autis dan siswa autis, guru mata pelajaran pendidikan agama Islam, waka kesiswaan dan kepala sekolah. Selanjutnya penelitian fokus perilaku dan prestasi belajar pendidikan agama Islam siswa autis di SMPN 5 Surabaya yang merupakan subjek dari penelitian ini.

Sumber data dalam penelitian ini diperoleh dengan cara melakukan observasi dan wawancara dengan kepala sekolah, guru pendidikan agama Islam. Data yang dihasilkan di antaranya data tentang kondisi dan keberadaan sekolah, fasilitas sekolah, kondisi tenaga pengajar, dan siswa. Selain itu, peneliti juga mencari data lain yang berasal dari dokumen pribadi, dokumen resmi sekolah, arsip, dan lain-lain. Data ini berguna untuk melengkapi data hasil observasi dan wawancara. Data dokumentasi yang dihasilkan dalam penelitian ini setidaknya memuat informasi tentang profil sekolah, visi dan misi sekolah. ${ }^{14}$

Setelah data yang diperlukan terkumpul, maka langkah selanjutnya adalah menganalisis data. Dalam menganalisis data, peneliti menggunakan hasil observasi, wawancara, dan dokumentasi, sehingga dapat dipertanggungjawabkan kebenarannya. Setelah itu, peneliti melakukan teknik pengecekan keabsahan data agar memperoleh data yang valid dan dipercaya oleh semua pihak melalui teknik triangulasi dengan membandingkan data yang diperoleh dari sumber lain dengan berbagai teknik dan waktu yang berbeda. Sebagai contoh

${ }^{14}$ Moleong, Metodologi Penelitian Kualitatif, 127. 
data yang diperoleh dari bawahannya atau data yang diperoleh dengan wawancara lalu dicek dengan observasi dan dokumentasi dalam waktu yang berbeda. ${ }^{15}$

\section{Perilaku Siswa Autis pada Pelaksanaan Pembelajaran Pendidikan Agama Islam}

Penelitian dilakukan di SMP Negeri 5 Surabaya. Letak sekolah SMP Negeri 5 di Jl. Rajawali 57 Surabaya Kecamatan: Krembangan. Desa/kel : Krembangan Selatan Surabaya 60175 Telp 3550149 , Fax 60175 dengan nomer statistik sekolah 201056003005 dan dengan nomor pokok sekolah nasional 20532563 memiliki nilai akreditasi sekolah A. SMP Negeri 5 Surabaya yang berstatus Negeri secara historis telah berdiri selama delapan puluh tahun yang tepatnya berdiri pada tanggal 1 Juli 1951 yang setidaknya telah memberikan banyak kontribusi terhadap pembangunan pendidikan di Indonesia khususnya di area Surabaya.

Sekolah ini merupakan sekolah yang berbasis Adiwiyata yang merupakan salah satu program kementerian negara lingkungan hidup dalam rangka mendorong terciptanya pengetahuan dan kesadaran warga sekolah dalam upaya pelestarian lingkungan hidup. Dalam program ini diharapkan setiap warga sekolah ikut terlibat dalam kegiatan sekolah menuju lingkungan yang sehat dan menghindarkan dampak lingkungan yang negatif. Di samping itu sekolah Adiwiyata ini

\footnotetext{
${ }^{15}$ Moleong, Metodologi Penelitian Kualitatif, 130.
} 
mempunyai tujuan, yaitu menciptakan kondisi yang baik bagi sekolah untuk menjadi tempat pembelajaran dan menyadarkan warga sekolah, sehingga di kemudian hari warga sekolah tersebut dapat turut bertanggung jawab dalam upaya-upaya penyelamatan lingkungan hidup dan pembangunan berkelanjutan. Tujuan yang kedua yaitu mewujudkan kelembagaan sekolah yang peduli yang berbudaya lingkungan bagi sekolah dasar dan menengah di Indonesia.

Berdasarkan hasil penelitian yang peneliti lakukan di SMP Negeri 5 Surabaya, terlihat bahwa secara berkesinambungan SMP Negeri 5 terus berupaya dalam meningkatkan kualitas pelayanan pendidikan. Hal ini berguna untuk mengantarkan semua anak didiknya baik itu anak didik yang normal maupun anak didik yang kurang normal dalam hal ini bisa dibilang anak autis untuk bisa menjadi anak berprestasi, paham akan semua ilmu baik itu ilmu agama dan ilmu umum dan bisa menjadi anak didik yang bermanfaat dalam hidup pribadi, bermasyarakat, dan bernegara.

Proses pelaksanaan pembelajaran siswa di SMP Negeri 5 Surabaya kelas VIII pada pembelajaran pendidikan agama Islam sudah bisa dikatakan maksimal. Hal ini tampak dari antusiasme guru dan siswa yang sama-sama besar dalam mempelajari ilmu agama khususnya, agama Islam. Melihat hal ini guru pendidikan agama Islam tidak langsung bangga karena di dalam kelasnya juga terdapat murid yang kurang beruntung dalam hal ini yaitu anak autis. 
Menurut Adam Doni, teman saya yang autis itu kadangkadang marah tanpa sebab, jahil, berbicara melantur, keluar kelas tanpa alasan dan tindakannya tidak terkontrol. Kalau teman saya yang autis itu sudah berkelakuan seperti itu, biasanya saya memilih untuk cuek. Sedangkan saat pelajaran agama Islam, teman saya yang autis ini kadang ikut pelajarannya kadang juga tidak. ${ }^{16}$

Selanjutnya, Nadya Nur Aini menuturkan bahwa perilaku teman autis itu suka memukul bangku, kadang-kadang marah, berimajinasi tinggi. Contoh imajinasinya itu biasanya menjadikan bangku seperti mobil dan bulpoint dijadikan seperti rokok. Terus kalau sudah bosan dengan pelajaran biasanya langsung keluar kelas atau pergi ke kantin. Kemudian saat pembelajaran pendidikan agama Islam itu kadang nyambung dan kadang tidak soalnya dia lama dalam menyerap pelajaran. ${ }^{17}$

Lebih lanjut, Ibnu Abbas memaparkan bahwa perilaku anak autis itu bisa dikatakan bertindak sesuka hatinya. Misalnya, dia itu tiba-tiba maju ke depan dan mengambil spidol kemudian menggambar di papan tulis. Akan tetapi perilaku seperti marahmarah, melempar sesuatu ke arah guru tidak pernah terjadi pada saya selama saya mengajar di SMP ini. Namun, pernah ada kejadian di kelas lain pada saat pembelajaran tiba-tiba seorang siswa autis memakan nasi bungkus. Setelah makanannya habis, wadah nasinya itu dilemparkan ke arah gurunya. Saya

\footnotetext{
${ }^{16}$ Adam Doni, Wawancara, Surabaya.

${ }^{17}$ Nadya Nur Aini, Wawancara, Surabaya.
} 
mengetahui kejadian tersebut karena saat kejadian itu, guru yang berada di kelas itu lari ke kelas sebelah yang kebetulan ada saya. Tapi saya berterima kasih karena selama saya mengajar semua murid, termasuk yang autis berkelakuan baik. ${ }^{18}$

Abbas juga menjelaskan bahwa pada awalnya anak-anak autis yang belum pernah mendapatkan penanganan mempunyai perilaku "cuek" atau semaunya sendiri. Untuk menjadikan mereka berperhatian perlu langkah-langkah dasar pendekatan, yaitu: kepatuhan, kontak mata, konsentrasi. Ketiga hal ini akan membentuk siswa autis bisa belajar dengan potensi yang mereka miliki sesuai perkembangannya. Berikut ini pemaparan mengenai langkah-langkah dasar pendekatan tersebut, antara lain:

a. Kepatuhan

Seorang anak autisme yang sudah tertera kepatuhannya dengan baik akan melebihi kepatuhan anak normal pada umumnya, karena pendidikan yang diterima pertama ini akan membentuk dirinya untuk melaksanakan kewajibannya. Dalam membentuk kepatuhan pada anak autisme para pengajar melatihnya dengan memberikan perintah (instruksi), yang harus dilakukan, berdo'a, bila tidak mau duduk, berdiri dan lain-lain.

b. Kontak mata

Anak autisme sebagaimana di atas bersikap cuek, maka agar perhatian harus melihat benda yang sedang diperhatikan

${ }^{18}$ Ibnu Abbas, Wawancara, Surabaya. 
mulai benda yang bentuknya besar sampai yang kecil, di samping itu anak-anak autisme susah dalam menginterpretasikan sesuatu. Contoh: dalam mengetahui warna, melihat benda dan lain-lain.

c. Konsentrasi

Dalam belajar harus konsentrasi agar apa yang disampaikan dapat terserap oleh otak. Maka dari itu bila anak-anak mempunyai konsentrasi yang tinggi mudah dalam belajar. Namun bagi anak-anak autisme untuk membentuk konsentrasi pada mereka dengan contoh: anak disuruh memperhatikan benda yang bergerak, ke kanan ke kiri, ke atas maupun ke bawah.

Menurut Abbas apabila tiga hal dasar itu yang dijadikan fundamen sudah terbentuk maka dijamin mereka akan dapat belajar dengan baik. Di sisi lain, Nur Hasanah menjelaskan bahwa selama pembelajaran berlangsung siswa kami (anak autis) kadang-kadang dapat dikendalikan dan terkadang bisa di luar kendali. Seperti kalau diajak masuk kelas saat pembelajaran dia tidak mau bahkan dia bisa lari-lari putar sekolah. Untuk mengatasi hal itu biasanya kita melakukan pendekatan secara emosional seperti kita bisa sering menyapa dia, melakukan kontak mata dengan dia agar siswa yang autis bisa kita kontrol untuk tidak bertindak berlebihan. Jika pendekatan secara emosional itu tidak terjadi, maka dia pun tidak akan 
menghiraukan kita, meskipun kita memanggilnya sampai lelahpun dia tidak akan menuruti kata-kata kita. ${ }^{19}$

Nur Hayati, guru pendamping khusus siswa inklusi menuturkan bahwa di sini kami memberikan beberapa terapi yaitu terapi okupasi, terapi edukasi dan terapi perilaku. Terapi okupasi ini untuk melatih agar anak autis ini bisa lebih patuh, selanjutnya terapi edukasi terapi ini kami gunakan untuk mendidik anak autis untuk bisa membaca menulis dan menghitung dan terapi perilaku, terapi perilaku ini kami arahkan kepada komunikasi, kalau komunikasinya bagus maka kepatuhan anak autis ini bisa dikendalikan, dia tidak akan bertindak semaunya sendiri. ${ }^{20}$

Jadi dapat penulis simpulkan bahwa tindakan anak autis yang kurang begitu bisa dikendalikan akan bisa mematuhi perintah gurunya dengan seringnya kita berinteraksi dengan dia. Cara berinteraksi dengan siswa autis itu dengan menggunakan terapi okupasi yang membuat anak itu patuh dan menggunakan kontak mata dengan siswa autis sehingga dia bisa konsentrasi dengan apa yang guru ucapkan. Jika siswa autis sudah berhasil dikondisikan dengan baik maka proses pembelajaran akan berlangsung dengan lancar. Dalam keterangan di bawah ini penulis akan membandingkan perilaku siswa normal dan perilaku siswa autis.

\footnotetext{
${ }^{19}$ Siti Nur Hasanah, Wawancara, Surabaya.

${ }^{20}$ Samsun Nur Hayati, Wawancara, Surabaya.
} 
Di bawah ini merupakan tabel perkembangan perilaku anak normal: ${ }^{21}$

\begin{tabular}{|c|c|c|}
\hline Usia & Kemampuan Motorik & Kemampuan Bicara \\
\hline Lahir & Fiksasi pandangan & Bereaksi terhadap suara \\
\hline 5 minggu & & Tersenyum sosial \\
\hline 2 bulan & $\begin{array}{l}\text { Mengikuti benda di garis } \\
\text { tengah }\end{array}$ & \\
\hline 3 bulan & Telapak tangan terbuka & Guu, Guuu \\
\hline 4 bulan & $\begin{array}{l}\text { Menyatukan kedua } \\
\text { tangan }\end{array}$ & $\begin{array}{l}\text { Orientasi terhadap suara; } \\
\text { A-guuu, Mengoceh }\end{array}$ \\
\hline 5 bulan & $\begin{array}{l}\text { Mengetahui adanya } \\
\text { benda kecil, } \\
\text { memindahkan benda } \\
\text { antara kedua tangan }\end{array}$ & Menoleh pada suara bel, \\
\hline 6 bulan & Meraih unilateral & $\begin{array}{l}\text { Mengoceh,Dada-dada, } \\
\text { Menggumam }\end{array}$ \\
\hline 7 bulan & Memeriksa benda & Menoleh pada suara bel \\
\hline 8 bulan & Memeriksa benda & $\begin{array}{l}\text { Mengerti perintah tidak } \\
\text { boleh, Da Da } \\
\text { dada tanpa arti, Ma ma } \\
\text { tanpa arti }\end{array}$ \\
\hline 9 bulan & Melempar benda & $\begin{array}{l}\text { Da dada, menoleh pada } \\
\text { suara bel }\end{array}$ \\
\hline 10 bulan & $\begin{array}{l}\text { Membuka penutup } \\
\text { mainan }\end{array}$ & \\
\hline 11 bulan & $\begin{array}{l}\text { Pincet grasp dengan jari, } \\
\text { meletakkan kubus dalam } \\
\text { gelas }\end{array}$ & $\begin{array}{l}\text { Mengerti perintah } \\
\text { ditambah mimik, mama } \\
\text { kata pertama selain } \\
\text { mama }\end{array}$ \\
\hline 12 bulan & $\begin{array}{l}\text { melepaskan benda } \\
\text { dengan sengaja, } \\
\text { mencoret, memasukkan } \\
\text { biji ke dalam } \\
\text { botol, minum dari gelas } \\
\text { tersendiri, } \\
\text { menggunakan sendok }\end{array}$ & Kata kedua \\
\hline 13 bulan & & Kata ketiga \\
\hline
\end{tabular}

${ }^{21}$ Yurike Fauzia Wardhani dkk, Autisme Terapi Medis Alternatif (Jakarta: Lembaga Penerbit Fakultas Ekonomi Universitas Indonesia, 2009), 1-3. 
Studi Perilaku

\begin{tabular}{|c|c|c|}
\hline 14 bulan & $\begin{array}{l}\text { Melepaskan biji dengan } \\
\text { meniru }\end{array}$ & $\begin{array}{l}\text { mengerti perintah tanpa } \\
\text { mimik }\end{array}$ \\
\hline 15 bulan & $\begin{array}{l}\text { Meniru membuat garis, } \\
\text { menyusundua } \\
\text { Kubus }\end{array}$ & 4-6 kata \\
\hline 16 bulan & $\begin{array}{l}\text { Melepaskan biji } \\
\text { spontan,menyusun tiga } \\
\text { kubus }\end{array}$ & \\
\hline 17 bulan & & $\begin{array}{l}\text { Menunjukkkan lima } \\
\text { bagian badan } \\
\text { yang disebutkan,7-20 } \\
\text { kata }\end{array}$ \\
\hline 18 bulan & $\begin{array}{l}\text { Membuat garis secara } \\
\text { spontan }\end{array}$ & \\
\hline 21 bulan & & Kalimat pendek dua kata \\
\hline 24 bulan & $\begin{array}{l}\text { Kereta api dengan } 4 \\
\text { kubus, membuka } \\
\text { baju sendiri }\end{array}$ & $\begin{array}{l}50 \text { kata, kalimat pendek } \\
2 \text { kata }\end{array}$ \\
\hline $25-27$ bulan & $\begin{array}{l}\text { Membuatgaris datar dan } \\
\text { tegak }\end{array}$ & \\
\hline 30 bulan & $\begin{array}{l}\text { Kereta api dengan } \\
\text { cerbong asap,meniru } \\
\text { dengan membuat } \\
\text { lingkaran }\end{array}$ & \\
\hline 3 tahun & $\begin{array}{l}\text { Membuat lingkaran } \\
\text { spontan, membuat } \\
\text { jembatan dari tiga kubus, } \\
\text { membuka kancing }\end{array}$ & $\begin{array}{l}250 \text { kata, kalimat terdiri } \\
\text { atas tiga } \\
\text { kata }\end{array}$ \\
\hline 4 tahun & $\begin{array}{l}\text { Membuat pintu gerbang } \\
\text { dari } 5 \text { kubus, } \\
\text { memasang kancing } \\
\text { Membuat pintu gerbang } \\
\text { dari } 5 \text { kubus, memasang } \\
\text { kancing }\end{array}$ & $\begin{array}{l}\text { Kalimat terdiri atas } 4-5 \\
\text { kata, bercerita, } \\
\text { menanyakan arti suatu } \\
\text { kata, menghitung } \\
\text { sampai } 20\end{array}$ \\
\hline 5 tahun & Mengikat tali sepatu & \\
\hline 6 tahun & $\begin{array}{l}\text { Membuat tangga dan } \\
\text { dinding dari } \\
\text { beberapa kubus tanpa } \\
\text { contoh }\end{array}$ & \\
\hline
\end{tabular}


Kriteria perilaku autisme yang ada di dalam DSM-IV: ${ }^{22}$

a. Harus ada sedikitnya enam gejala dari (1), (2), dan (3) dengan minimal 2 gejala dari (1) dan masing-masing1 gejala dari (2) dan (3).

1) Gangguan kualitatif dalam interaksi sosial yang timbal balik. Minimal dua gejala dari gejala-gejala di bawah ini :

a) Tak mampu menjalin interaksi sosial yang cukup memadai: kontak mata sangat kurang, ekspresi mata yang kurang hidup, gerak-gerik yang kurang tertuju.

b) Tidak bisa bermain dengan teman sebayanya.

c) Tak dapat merasakan apa yang dirasakan orang lain.

d) Kurangnya hubungan sosial dan emosional yang timbal balik.

2) Gangguan kualitatif dalam bidang komunikasi. Minimal satu dari gejala-gejala di bawah ini :

a) Bicara terlambat atau bahkan sama sekali tidak berkembang (tidak ada usaha untuk mengimbangi komunikasi dengan cara lain tanpa bicara).

b) Bila bisa bicara, bicaranya tidak dipakai untuk komunikasi.

c) Sering menggunakan bahasa yang aneh dan diulangulang.

${ }^{22}$ Christopeh Sunu, Unlocking Autism (Yogyakarta: Lintang Terbit, 2012), 13-14. 
d) Cara bermain yang kurang variatif, kurang imajinatif, dan kurang bisa meniru.

3) Suatu pola yang dipertahankan dan diulang-ulang dari perilaku, minat, dan kegiatan sedikitnya harus ada satu dari gejala-gejala di bawah ini:

a) Mempertahankan satu minat atau lebih, dengan cara yang sangat khas dan berlebih-lebihan.

b) Terpaku pada suatu kegiatan yang ritualistik atau rutinitas yang tidak berguna.

c) Ada gerakan-gerakan yang aneh dan diulang-ulang.

d) Seringkali terpaku pada bagian-bagian benda.

b. Sebelum umur tiga tahun tampak adanya keterlambatan atau gangguan dalam bidang: interaksi sosial, bicara dan berbahasa, cara bermain yang kurang variatif

c. Bukan disebabkan oleh sindroma rett atau gangguan disintegratif masa kanak.

Selain menggunakan DSM-IV, dapat juga menggunakan daftar indikator perilaku autis pada anak-anak di bawah ini untuk menambah data ada tidaknya ciri-ciri autisme pada anak:

a. Bahasa dan komunikasi

1) Ekspresi wajah datar

2) Tidak menggunakan bahasa atau isyarat tubuh

3) Jarang memulai komunikasi

4) Tidak meniru aksi atau suara

5) Bicara sedikit atau tidak ada, atau mungkin cukup verbal 
6) Mengulangi atau membeo kata-kata, kalimatkalimat, atau nyanyian

7) Intonasi atau ritme volak yang aneh

8) Tampak tidak mengerti arti kata

9) mengerti dan menggunakan kata secara terbatasi

b. Hubungan dengan orang lain

1) Tidak responsif

2) Tidak ada senyum sosial

3) Tidak berkomunikasi dengan mata

4) Kontak mata terbatas

5) Tampak asyik bila dibiarkan sendiri

6) Tidak melakukan permainan giliran

7) Menggunakan tangan orang dewasa sebagai alat

c. Hubungan dengan lingkungan

1) Bermain repetitif (diulang-ulang)

2) Marah atau tidak menghendaki perubahan

3) Perkembangan rutinitas yang kaku (rigid)

4) Memperlihatkan ketertarikan yang sangat dan tidak fleksibel

d. Respon terhadap rangsangan indera atau sensorik

1) Kadang seperti tuli

2) Kadang terhadap suara-suara tertentu

3) Sangat sensitif terhadap suara

4) Bermain-bermain dengan cahaya dan pantulan

5) Memainkan jari-jari di depan mata

6) Menarik diri ketika disentuh 
7) Sangat tidak suka terhadap pakaian dan makanan atau hal tertentu

8) Tertarik pada pola atau tekstur atau bau tertentu

9) Sangat inaktif atau hiperaktif

10) Mungkin memutar-mutar, berputar-putar, membentur-benturkan kepala, menggigit pergelangan

11) Melompat-lompat atau mengepak-ngepakkan tangan

12) Tahan atau berespon aneh terhadap nyeri

e. Kesenjangan perkembangan perilaku

1) Kemampuan mungkin sangat baik atau sangat terlambat

2) Mempelajari keterampilan di luar urutan normal, misalnya membaca tak mengerti arti

3) Menggambar secara rinci, tapi tidak dapat mengancing baju

4) Pintar mengerjakan puzzle, tapi amat sukar mengikuti perintah

5) Berjalan pada usia normal, tetapi tidak berkomunikasi

6) Lancar membeo bicara, tapi sulit bicara dari diri sendiri (inisiatif komunikasi)

7) Suatu waktu dapat melakukan sesuatu, tetapi tidak lain waku 
Dari perbandingan perilaku di atas antara siswa autis dengan siswa normal maka akan penulis bandingkan dengan kenyataan yang ada di lapangan.

Pernyataan yang diungkapkan oleh Adam Doni mengenai temannya yang autis ini berbeda dengan siswa normal di kelasnya, siswa autis menunjukkan perilaku yang berbeda, misalnya tiba-tiba marah tanpa sebab, berbicara melantur, dan kadang bertindak tidak terkontrol. Sedangkan siswa normal berperilaku disiplin serta tertib dalam mengikuti proses pembelajaran.

Selanjutnya Nadya Nur Aini berpendapat bahwa teman belajar anak autis yang ada di kelasnya sering menunjukkan sikap tidak bisa terkontrol, misalnya berimajinasi dengan barang-barang di sekelilingnya pada saat pembelajaran berlangsung sehingga mengganggu proses belajar-mengajar di kelas, terkadang kalau sudah bosan anak autis keluar begitu saja dari kelas dan tidak mengikuti proses pembelajaran. Hal ini berbeda dengan siswa normal lainnya, mereka mengikuti proses pembelajaran secara baik, mendengarkan guru menjelaskan materi pelajaran dan mengerjakan tugas yang diberikan guru dengan baik.

Berdasarkan hasil wawancara dengan Ibnu Abbas, guru mata pelajaran pendidikan agama Islam, dapat penulis simpulkan bahwa perilaku anak autis dan anak normal di kelas memiliki perbedaan yang signifikan. Siswa autis tidak bisa mengikuti proses pembelajaran secara tertib karena kekurangan 
yang dimilikinya, bahkan seringkali merepotkan guru dan teman-temannya, tetapi masih dalam batas normal. Sedangkan siswa normal sanggup mengikuti proses pembelajaran secara tertib dan lancar. Selain itu juga diperlukan teknik dan cara-cara khusus dalam membimbing para siswa autis, supaya dapat mewujudkan dan mengembangkan potensi, kemampuan, dan sikap yang mereka miliki sesuai perkembangannya masingmasing.

Penjelasan dari guru agama Islam bahwa kelakuan anak autis itu biasanya suka bertindak semaunya sendiri, tiba-tiba jalan ke depan kelas mengambil spidol dan menggambar sesuatu di papan tulis, tapi itu semua sudah dikendalikan dengan baik, karena guru pendidikan agama Islam setiap hari memberi beberapa kebiasaan yaitu kontak mata, kepatuhan dan konsentrasi.

Hal ini diperjelas dengan argumen koordinator siswa autisme yang menjelaskan bahwa untuk mengatur siswa autis bisa dilakukan dengan cara pendekatan emosional. Dengan contoh, seperti kita sering menyapa siswa autis, mengajak bicara dia, dengan hal itu maka kepatuhan akan mudah tercapai bila ada seseorang guru yang menyuruh atau memerintah sesuatu kepada siswa autis.

Koordinator guru pendamping khusus juga menjelaskan bahwa untuk mengatur atau untuk mentertibkan siswa autis biasanya bisa menggunakan terapi okupasi dan terapi perilaku, hal ini sangat efetif dilakukan kepada siswa autis karena dalam 
hal ini siswa autis disuruh untuk menulis kesalahan yang ia lakukan dan selanjutnya diberi perintah bahwa perbuatan ini jelek atau perbuatan ini bisa dikategorikan baik.

\section{Prestasi Belajar Pendidikan Agama Islam Siswa Autis}

Evaluasi pendidikan bagi anak autis di SMP Negeri 5 Surabaya dilaksanakannya sesuai dengan jadwalnya. Dalam hal ini, ujian dilakukan bersama-sama siswa normal dan satu kelas tapi soal ujiannya dibedakan antara siswa normal dan siswa autis. Arleni menegaskan bahwa, soal untuk siswa autis akan dibedakan dengan siswa yang normal. Untuk nilai minimal kelulusan pendidikan agama Islam bagi siswa autis yaitu 75 . Dan dengan adanya ujian dengan soal tersendiri maka raportnya juga disendirikan dengan rapot siswa normal. ${ }^{23}$

Nur Hasanah juga menjelaskan bahwa, evaluasi di sini menggunakan soal berbeda. Pembuatan soal kami menyerahkan kepada guru pendidikan agama Islam yang kami tunjuk, dalam hal ini kami menunjuk Wiwiekningsih, semua soal agama Islam dibuat berdasarkan pengetahuan atau disesuaikan dengan kemampuan siswa autis. Seperti kalau bobot nilai 75 siswa normal akan berbeda dengan nilai 75 siswa autis. Itupun kadang-kadang ada salah satu siswa yang bisa mengerjakan ada juga yang tengah-tengah.

Mengenai raport untuk siswa autis ini akan disendirikan dengan siswa yang normal. Aka tetapi, siswa autis tidak

\footnotetext{
${ }^{23}$ Dian Arleni, Wawancara, Surabaya.
} 
diwajibkan untuk mengikuti ujian nasional yang diadakan pemerintah dan hal ini tidak mempengaruhi untuk memperoleh ijazah. ${ }^{24}$ Berkaitan dengan ini, Sisminarto, kepala sekolah SMP Negeri 5 menegaskan bahwa, ijazah sekolah siswa autis tetap ada dan akan diberi oleh pemerintah tapi ijazah itu akan berbeda dengan ijazah kelulusan siswa normal. Sedangkan mengenai prestasi pendidikan agama Islam siswa autis di sekolah ini sudah dapat dikatakan cukup dikarenakan input siswa sudah memenuhi standart penerimaan siswa autis yang dilaksanakan oleh panitia penerimaan siswa baru. $^{25}$

Dalam hal ini, Abbas menyatakan bahwa anak autis itu anak yang pintar dalam satu hal, seperti dia suka berhitung maka kepintaran berhitungnya itu akan melebihi anak normal, dalam hal prestasi pendidikan agama Islam anak autis akan bersifat lebih sopan santun terhadap gurunya, temannya, orang tuanya dan semua orang di sekitarnya. Hal ini merupakan prestasi perubahan tingkah lakunya yang mencerminkan ajaran agama Islam. Tapi itu semua tidak luput dari proses pembelajaran yang baik dan tuntasnya evaluasi pembelajaran yang telah dilakukan. $^{26}$ Nur Hayati juga menegaskan bahwa, prestasi pendidikan agama Islam anak autis ini saya hanya mengukur dari sikap saja, seperti si anak ini dari kelakuannya yang

\footnotetext{
${ }^{24}$ Siti Nur Hasanah, Wawancara, Surabaya.

${ }^{25}$ Sisminarto, Wawancara, Surabaya.

${ }^{26}$ Ibnu Abbas, Wawancara, Surabaya.
} 
biasanya kurang sopan sekarang menjadi sopan terhadap guruguru di sini. ${ }^{27}$

Prestasi anak autis ini sudah menunjukkan prestasi belajar yang baik, hal ini dibuktikan dengan tuntasnya sejumlah mata pelajaran yang telah diujikan oleh sekolah, termasuk tuntasnya ujian mata pelajaran pendidikan Agama Islam dan perilaku baik yang dicerminkan setelah mendapat pembelajaran pendidikan agama Islam. Di samping prestasi akademik, siswa autis ini juga mempunyai sederetan prestasi non akademik yang telah mereka raih untuk SMP Negeri 5 Surabaya. Prestasi ini semua tidak luput dari berbagai proses yang telah dilakukan oleh sekolah dari mulai pendaftaran dan proses pendidikan yang ada di SMP Negeri 5 Surabaya sebagaimana dapat dilihat dalam penjelasan berikut ini:

Prestasi anak autis di sini mungkin lebih menonjol pada sisi non akademiknya, kalau nilai akademik pendidikan agama Islam biasa-biasa saja itu semua jelas kalah dengan anak normal pada umumnya tapi dengan semua itu kami puas karena nilai pendidikan agama Islamnya sudah memenuhi standar ketuntasan. Tapi untuk masalah prestasi non akademik anak autis ini tidak kalah dengan anak normal, seperti juara harapan I tenis meja dispora, juara harapan I tenis meja, juara II futsal dan harapan I bola basket. ${ }^{28}$

Dari poin ini dapat penulis simpulkan bahwa prestasi pendidikan agama Islam anak autis sudah memenuhi standar kelulusan yang telah ditetapkan oleh SMP Negeri 5 Surabaya,

${ }^{27}$ Samsun Nur Hayati, Wawancara, Surabaya.
${ }^{28}$ Siti Nur Hasanah, Wawancara, Surabaya. 
itu semua bisa diwujudkan dengan banyak pihak yang membantu anak autis dalam mencapai nilai prestasi pendidikan agama Islam. Di samping prestasi akademik, anak autis ini juga menonjol dalam prestasi non akademik, seperti tenis meja, futsal dan bola basket.

Kuota untuk anak autis yang terdapat di SMP Negeri 5 Surabaya yaitu 18 orang. Hal ini didasarkan pada jumlah kelas yang ada, di sini kelas yang ada sekarang yaitu tiap jenjang tingkatan kelas dari kelas tujuh sampai sempilan terdapat delapan kelas, tapi jumlah itu akan bertambah tahun depan seiring dengan penambahan satu kelas yang akan dilakukan pemerintah kota Surabaya seperti perkataan yang penulis kutip dari kepala sekolah SMP Negeri 5 Surabaya.

Mengenai pendaftaran siswa autis yang ada di sekolah ini yaitu pertama-tama orang tua wali murid harus mempunyai surat keterangan dari psikolog setempat yang menerangkan bahwa anak ini merupakan anak didik autis. Selanjutnya panitia penerimaan murid baru akan menyeleksi siswa autis yang akan mendaftar di sekolah ini, dalam hal ini sekolah akan lebih mengutamakan prestasi siswa, siswa yang dekat dengan wilayah sekolah, database pemerintah kota Surabaya dan mereka merupakan data tetap kartu susunan keluarga pemerintah kota Surabaya.

Waka kurikulum di sini juga memberi pendapat mengenai kurikulum yang digunakan anak autis yaitu kurikulumnya sesuai dengan kurikulum anak biasanya atau anak normal, dalam hal 
ini disamakan karena pemerintah belum menetapkan kurikulum pendidikan yang dikhususkan kepada anak didik autis yang ada di lembaga sekolah negeri. Dengan adanya penyamaan kurikulum dengan anak normal maka guru-guru di SMP Negeri 5 Surabaya menyesuaikan kurikulum tersebut dengan siswa autis, hal itu juga berlaku pada rencana pelaksanaan pembelajaran di kelas.

Sedangkan metode yang digunakan dalam pembelajaran di kelas menggunakan metode ceramah, diskusi dan menggunakan media pembelajaran. Hal ini sesuai dengan apa yang dituturkan oleh guru pembelajaran pendidikan agama Islam yang menyatakan bahwa dalam pembelajaran guru pendidikan agama Islam menggunakan metode ceramah sebanyak 20 persen, metode diskusi 30 persen dan menambahkan media pembelajaran proyektor dengan prosentase 100 persen.

Tapi dalam hal metode yang digunakan guru pendamping khusus dalam hal terapi yang diberikan pada siswa autis setiap hari Sabtu, mereka meminimalkan penggunaan metode ceramah dan memperbanyak alat peraga karena dalam hal ini anak autis kurang begitu merespon dan kurang bisa memahami pelajara jika kita melakukan metode ceramah.

Lebih lanjut, evaluasi yang digunakan pada anak autis ini sesuai dengan jadwal yang ditetapkan sekolah. Dalam hal ini soal akan dibuat secara tersendiri dengan bobot tersendiri pula. Semisal bobot kelulasan pendidikan agama Islam siswa normal yaitu 75 , maka nilai 75 ini akan berbeda bobot soalnya dengan 
nilai 75 anak autis. Kadang-kadang juga evaluasi yang dilakukan dengan memberi pertanyaan secara berhadaphadapan. Dengan adanya soal tersendiri ini maka siswa autis bisa lebih efektif dalam mengikuti evaluasi pembelajaran yang dilakukan oleh sekolah. Evaluasi ini juga akan mendapat ijazah khusus pula karena siswa autis ini tidak diwajibkan untuk ikut ujian nasional.

Rangkaian proses pelaksanaan pembelajaran yang secara runtut tersebut telah membuahkan hasil yang cukup memuaskan dengan tuntasnya sejumlah pembelajaran yang sedang ditempuh siswa autis, khususnya tuntasnya pembelajaran pendidikan agama Islam yang sesuai dengan nilai ketuntasan minimal yang telah ditetapkan sekolah. Maka dengan ini prestasi pendidikan agama Islam anak autis sudah bisa dikatakan sebagi prestasi yang cukup membanggakan.

\section{Penutup}

Gangguan perilaku pada anak autis menurut kriteria DSMIV yaitu tak mampu menjalin interaksi sosial yang cukup memadai: kontak mata sangat kurang, ekspresi mata yang kurang hidup, gerak-gerik yang kurang tertuju. Tidak bisa bermain dengan teman sebayanya. Tak dapat merasakan apa yang dirasakan orang lain. Kurangnya hubungan sosial dan emosional yang timbal balik. Kemudian penulis hubungan dengan keadaan di lapangan maka akan ada kecocokan yang dilakukan oleh anak autis dengan kriteria yang telah ditentukan 
di kriteria DSM-IV, jadi perilaku siswa autis pada dasarnya semua sama tergantung pada perbedaan tingkat gejala autisme yang siswa autis derita. Setelah itu perilaku siswa autis akan diarahkan kepada perilaku yang mencerminkan ajaran-ajaran agama Islam, seperti bertingkah sopan terhadap guru, menghormati guru dan patuh terhadap apa yang diperintahkan oleh guru.

Untuk prestasi belajar pendidikan agama Islam yang sudah dicapai siswa autis di SMP Negeri 5 Surabaya sudah cukup membanggakan. Itu semua dapat dilakukan oleh SMP Negeri 5 Surabaya melalui banyak proses, di antaranya pengambilan siswa autis yang berprestasi, kurikulum yang digunakan, metode pembelajaran dan evaluasi yang digunakan. Prestasi ini dibuktikan dengan tuntasnya mata pelajaran pendidikan agama Islam yang sesuai dengan standar kelulusan yang telah ditetapkan sekolah, dan beberapa prestasi non akademik.

\section{Daftar Rujukan}

Abbas, Ibnu. Wawancara. Surabaya.

Aini, Nadya Nur. Wawancara. Surabaya.

Arikunto, Suharsimi. Manajemen Penelitian. Yogyakarta: Rineka Cipta, 2012.

Arleni, Dian. Wawancara. Surabaya.

Christopeh, Sunu. Unlocking Autism. Yogyakarta: Lintang Terbit, 2012.

Doni, Adam. Wawancara. Surabaya. 
Handojo, Y. Autisma Petunjuk Praktis dan Pedoman Materi untuk Mengajar Anak Normal Autis dan Perilaku Lain. Jakarta: Buana Ilmu Populer, 2003.

Hasanah, Siti Nur. Wawancara. Surabaya.

Hayati, Samsun Nur. Wawancara. Surabaya.

Mardalis, Metode Penelitian Suatu Pendekatan. Jakarta: Bumi Aksara, 2011.

Moleong, Lexy J. Metodologi Penelitian Kualitatif. Bandung: Remaja Rosda Karya, 2009.

Munandar, Utami. Kreatifitas dan Keberbakatan. Jakarta: Gramedia, 2002.

Nazir, Muhammad. Metode Penelitian. Bandung: Remaja Rosda Karya, 2010.

Safaria, Trianto. Autisme. Yogyakarta: Graha Ilmu, 2005.

Santosa, Slamet. Psikologi Klinis. Jakarta: UI Press, 2003.

Sisminarto. Wawancara. Surabaya.

Smith, J. David. Inklusi Sekolah Ramah untuk Semua. Bandung: Nuansa, 2006.

Undang-undang Republik Indonesia No. 20 tahun 2003 tentang Sistem Pendidikan Nasional. Bandung: Citra Umbara, 2003.

Wardhani, Yurike Fauzia dkk. Autisme Terapi Medis Alternatif. Jakarta: Lembaga Penerbit Fakultas Ekonomi Universitas Indonesia, 2009.

Wood, Derek dkk. Kiat Mengatasi Gangguan Belajar. Yogyakarta: Kata Hati, 2005. 